Volume 8, No.1, Januari 2022

P-ISSN 2442-2436, E-ISSN: 2550-0120

Akreditasi Ristekdikti, No: 36/E/KPT/2019 (Sinta 4)

DOI: $10.31294 /$ jtk.v4i2

\title{
Sistem Pendukung Keputusan Penerima Bantuan Langsung Tunai Menggunakan Simple Additive Weighting (SAW) Di Desa Sukatenang
}

\author{
Lusa Indah Prahartiwi', Dede Rosita² \\ 1,2Universitas Nusa Mandiri \\ 1e -mail: lusa.lip@nusamandiri.ac.id \\ 2e-mail: dederosita726@gmail.com
}

\begin{tabular}{ccc}
\hline Diterima & Direvisi & Disetujui \\
$15-09-2021$ & $05-10-2021$ & $13-01-2022$ \\
\hline
\end{tabular}

\begin{abstract}
Abstrak - Desa Sukatenang adalah salah satu desa yang menyalurkan program Bantuan Langsung Tunai (BLT). Dengan banyaknya jumlah penduduk yang mengusulkan untuk mendapatkan BLT ini membuat pemerintah desa kesulitan dalam menyeleksi penerima BLT. Pemerintah desa membutuhkan solusi terbaik agar penyaluran BLT dapat disalurkan secara adil dan tepat sasaran. Dengan permasalahan tersebut, maka diperlukan sistem pendukung keputusan yang akan membantu pihak desa untuk memberikan hasil yang terbaik. Penelitian ini menggunakan metode Fuzzy Multiple Attribute Decision Making (FMADM) dengan mengambil salah satu penyelesaiannya adalah Simple Additive Weighting yang sering disebut dengan metode penjumlahan terbobot dari rating alternatif pada semua atribut. Kriteria yang digunakan yaitu kondisi rumah, penghasilan, jumlah tanggungan dan pekerjaan. Banyaknya data yang dijadikan alternatif pada penelitian ini sebesar 91 data. Berdasarkan hasil penelitian ini, alternatif dengan rank tertinggi V38 = 1,00 atau A38 dengan nama alternatif "Mahmuddin". Namun ada beberapa alternatif dengan nilai yang cukup dan tidak kurang dari 0,90 adalah A62, A86, A59, A57, A58, A66, A76, A23 dan A8 yang terpilih sebagai alternatif terbaik dalam penerima BLT.
\end{abstract}

Kata Kunci: Bantuan Langsung Tunai, Sistem Pendukung Keputusan, Simple Additive Weighting

\begin{abstract}
Sukatenang Village is one of the villages that distributes the Direct Cash Assistance (BLT) program. With the large number of people proposing to get BLT, it is difficult for the village government to select BLT recipients. The village government needs the best solution so that the distribution of BLT can be distributed fairly and on target. With these problems, a decision support system is needed that will help the village to provide the best results. This study uses the method of Fuzzy Multiple Attribute Decision Making (FMADM) by taking one of the solutions is Simple Additive Weighting which is often referred to as the weighted addition method of alternative ratings on all attributes. The criteria used are the condition of the house, income, number of dependents and work. The amount of data that is used as an alternative in this study is 91 data. Based on the results of this study, the alternative with the highest rank is V38 = 1.00 or A38 with the alternative name "Mahmuddin". However, there are several alternatives with sufficient value and not less than 0.90, namely A62, A86, A59, A57, A58, A66, A76, A23 and A8 which were chosen as the best alternative in BLT recipients.
\end{abstract}

Keywords: Direct Cash Assistance, Decision Support System, Simple Additive Weighting

\section{PENDAHULUAN}

Bantuan Langsung Tunai sering dikenal dengan BLT yang merupakan salah satu program bantuan pemerintah dengan memberikan bantuan berupa uang tunai atau pun berbagai bantuan yang lain, yang bersyarat atau pun tidak bersyarat diberikan kepada masyarakat yang kurang mampu. Pemberian dana BLT disesuaikan dengan kebijakan pemerintah nasional (Santoso \& Royal Kisaran, 2019). Di Negara Indonesia sendiri sudah banyak menyelenggarakan program Bantuan sosial dengan berbagai jenis pemberian, seperti BLT, bansos sembako, PKH, bedah rumah dan lain-lain dengan target pemberian yaitu kepada masyarakat yang kurang mampu. Dengan adanya pandemi sekarang ini, banyak sekali perubahan pada sisi kehidupan warga di desa maupun di kota. Di daerah terpencil seperti desa-desa kurang maju ataupun desa-desa tertinggal yang umumnya mempunyai jumlah warga yang cukup besar tentunya terdapat masalah seperti pemilihan penerima bantuan menjadi semakin kompleks, dikarenakan terlalu

http://ejournal.bsi.ac.id/ejurnal/index.php/jtk 
banyak warga antara yang mengusulkan bantuan dengan jumlah warga yang diterima untuk pemberian BLT tersebut. Dari banyaknya jumlah penduduk yang mengusulkan pastinya ini membuat pemerintah desa kesulitan untuk menyeleksi warga penerima BLT tersebut.. Dengan demikian pemerintah desa harus lebih teliti lagi dalam pemilihan warga yang akan diberi bantuan sehingga warga yang diberi benarbenar layak menerimanya dan dari golongan yang kurang mampu. Terlebih di masa pandemic ini, tentunya banyak warga yang kehilangan pekerjaannya, pastinya hal ini menjadi masalah dalam kelangsungan dan kesejahteraan hidup mereka.

Berdasarkan penelitian sebelumnya (Sembiring et al., 2020). Di dalam penelitian tersebut, menjelaskan bahwa permasalahan yang terjadi pada masa pandemi COVID-19 yaitu meningkatnnya angka kemiskinan. Dengan hal itu pemerintahpun berencana memberikan bantuan khusus untuk masyarakat yang tidak mampu. Kemudian, untuk mendapatkan bantuan keuangan dari covid-19, kita harus menyetujui aturan dan standar yang telah ditetapkan, dan standar dalam studi kasus ini adalah pekerjaan, tanah tempat tinggal, listrik, dan lain-lain. Untuk menyelesaikan permasalahan tersebut, metode Simple Additive Weighting dipilih karena dapat menentukan nilai bobot pada setiap atribut yang sudah ditentukan sehingga akan mendapatkan hasil yang lebih akurat terhadap siapa yang akan menerima bantuan pemerintah tersebut. Metode Simple Additive Weighting adalah metode yang dikenal dan paling banyak digunakan untuk menangani Situasi MADM (Multiple Attribute Decision Making) (Sahir et al., 2017). Keuntungan dari metode ini yaitu transformasi linier proporsional dari data mentah yang berarti bahwa urutan relatif besarnya skor standar tetap sama (Tan et al., 2014)

Sistem Pendukung Keputusan adalah sistem informasi yang menyediakan informasi, pemodelan dan data (Rahmawati \& Apriyanto, 2021). Pada penelitian yang dilakukan ini akan dibuat metode keputusan untuk menyelesaikan masalah Multiple Attribut Decision Making (MAMD), yang mempunyai kinerja sangat efektif dengan data-data serta nilainya kisaran dari jangkauan nilai tertentu. Multiple Attribut Decision Making merupakan metode yang digunakan untuk mencari alternatif optimal dari sejumlah alternatif dengan kriteria tertentu (Sobari et al., 2017). Oleh karena itu, Multiple Attribut Decision Making biasanya digunakan untuk melakukan penilaian atau seleksi terhadap beberapa alternatif dalam jumlah yang terbatas (Refiza, 2019). Teknik yang paling populer untuk mendukung proses pengambilan keputusan yaitu Simple Additive Weighting method (SAW)/Simple Multi Attribute Rating Technique (SMART), Analytic Hierarchy Process, dan Technique for Order of Preference by Similarity to
Ideal Solution (TOPSIS) (Piasecki \& Roszkowska, 2019). Untuk metode yang menyelesaikan masalah keputusan di dalam penelitian ini menggunakan metode Simple Additive Weighting. yang dapat menentukan nilai pembobotan pada masing-masing atribut dan dilanjutkan proses peranking. Kriteria yang akan ditentukan dalam penelitian ini, yaitu dilihat dari penghasilan, pekerjaan, jumlah tanggungan dan kondisi rumah. Kriteria yang telah ditentukan pada penelitian ini dapat mempermudah peneliti untuk mengolah data pada program penerima bantuan agar dilakukan secara adil, tepat sasaran serta sesuai dengan kriteria yang telah memenuhi syarat sebagai penerima Bantuan Langsung Tunai. Diharapkan dengan menggunakan metode Simple Additive Weighting dapat membantu untuk memecahkan masalah dengan menyeleksi di dalam perhitungan alternatif serta menentukan kriteriakriteria yang sesuai dalam penerimaan program Bantuan Langsung Tunai tersebut secara tepat sasaran terhadap masyarakat yang kurang mampu terlebih pada masa pandemi seperti ini.

\section{METODOLOGI PENELITIAN}

Pada tahap penelitian, tentunya ada beberapa langkah untuk keberhasilan suatu tujuan yang telah direncanakan sebelumnya. Adapun tahapan-tahapan dalam penelitian ini disajikan pada Gambar 1.

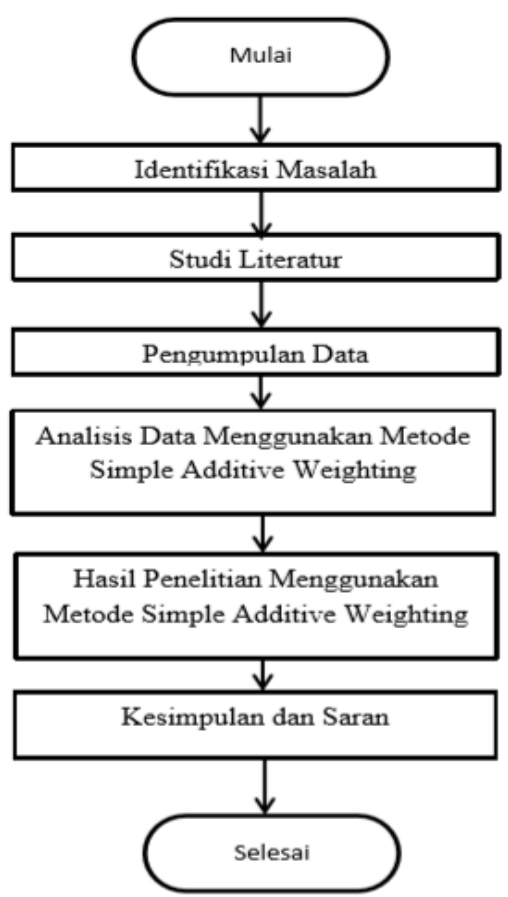

Sumber: Hasil Penelitian (2021)

Gambar 1. Tahapan Penelitian

Pada Gambar 1, dijelaskan bahwa tahapan penelitian diawali dengan identifikasi masalah berdasarkan dengan rumusan permasalahan yang telah diuraikan pada latar belakang penelitian. Kemudian melakukan studi literatur dan pengumpulan data. Pengumpulan 
data dilakukan dengan observasi langsung di Kantor Desa Sukatenang, yang beralamat Jl. Raya Sukatenang No. 160, Sukatenang, Sukawangi, Bekasi, Jawa Barat 17620 serta melakukan wawancara dengan Kepala Desa Sukatenang, Sekretaris Desa Sukatenang dan Ketua Rt 002/012. Setelah semua data terkumpul, peneliti melakukan analisis dan pengolahan data menggunakan Metode Simple Additive Weighting sehingga menghasilkan alternatif terbaik dalam penerima program BLT.

Instrument penelitian merupakan alat-alat yang dibutuhkan dalam mengumpulkan, menganalisa sampai pengolahan data-data sebuah penelitan. Penyusunan instrument bertujuan memecahkan suatu permasalahan dan hasil yang diperoleh bisa menjadi tolak ukur untuk memakai standarisaasi yang sebelumnya telah ditetapkan oleh peneliti (Nandes \& Yunus, 2021). Untuk menentukan sampel penelitian serta besaran sampel yang digunakan peneliti diambil dengan menggunakan rumus slovin (Malik \& Haryanti, 2018).

$n=\frac{N}{1+N e^{2}}$

$n=\frac{1051}{1+\left(1051 \times 10 \%^{2}\right)}=91,3$ dibulatkan menjadi 91

Pada penelitian yang dilakukan ini menggunakan instrument kuesioner dengan wawancara kepada pihak kantor Desa sukatenang dan menyebar kuesioner diwilayah Desa Sukatenang. Data yang peneliti gunakan yaitu sebanyak 91 data untuk dijadikan sebagai alternatif penerima Bantuan Langsung Tunai pada Desa Sukatenang, data sampel yang pilih yaitu warga yang berada di wilayah Desa Sukatenang. Dalam penelitian yang dilakukan ini, peneliti menggunakan sebuah metode pada sistem pendukung keputusan yaitu menggunakan metode Simple Additive Weighting. Metode ini mengharuskan pengambil keputusan untuk melakukan penetuan pembobotan pada masingmasing atribut atau kriteria yang digunakan dalam penelitian tersebut (Rahmawati \& Apriyanto, 2021).

Algoritma perhitungan Simple Additive Weighting sebagai berikut:

1. Melakukan penentuan alternatif, yaitu (Ai), dan kriteria atau atribut $(\mathrm{Cj})$.

2. Melakukan nilai rating kecocokan setiap alternatif pada setiap kriteria.

3. Memberikan nilai bobot preferensi atau tingkat kepentingan $(\mathrm{W})$.

$\mathrm{W}=[\mathrm{W} 1, \mathrm{~W} 2, \mathrm{~W} 3, \mathrm{~W} 4 \ldots . \mathrm{Wj}]$

4. Selanjutnya membuat matriks keputusan (X) dari tabel rating kecocokan dari setiap alternatif serta kriteria.

$$
\mathrm{X}=\left[\begin{array}{cccc}
x_{11} & x_{12} & \ldots & x_{1 n} \\
x_{21} & x_{22} & \ldots & x_{2 n} \\
\ldots & \ldots & \ldots & \ldots \\
x_{m 1} & x_{m 2} & \ldots & x_{m n}
\end{array}\right]
$$

5. Membuat perhitungan proses normalisasi matriks keputusan (X) ke suatu skala yang dapat diperbandingkan dengan semua ranting alternatif yang ada.

$r_{i j}=\left\{\begin{array}{c}x_{i j} \\ \frac{\max _{i} x_{i j}}{\min _{i} x_{i j}} \\ x_{i j}\end{array}\right\}$

6. Melakukan perkalian matriks ternormalisasi (R) dari hasil normalisasi matriks (Rij).

$R=\left[\begin{array}{cccc}r_{11} & r_{12} & \ldots & r_{1 n} \\ r_{21} & r_{22} & \ldots & r_{2 n} \\ \ldots & \ldots & \ldots & \ldots \\ r_{m 1} & r_{m 2} & \ldots & r_{m n}\end{array}\right]$

7. Membuat hasil perangkingan untuk tiap alternatif (Vi) dengan cara menjumlahkan kali antara matriks ternormalisasi (R) dengan bobot (W). maka akan didapatkan nilai (Vi) dari nilai tertinggi sampai dengan nilai terendah.

$v i=\sum_{j=1}^{n} W i_{r i j}$

\section{HASIL DAN PEMBAHASAN}

1. Menentukan Data Alternatif

Data yang akan dijadikan alternatif penerima Bantuan Langsung Tunai sebanyak 91 data yang diambil melalui penyebaran kuesioner pada wilayah Desa Sukatenang. Tentunya peneliti sudah meminta izin terlebih dahulu kepada pihak Desa untuk dijadikan bahan penelitian. Serta wawancara yang dilakukan terdapat pemilihan kriteria yang akan dijadikan acuan perhitungan Simple Adiitive Weighting yaitu dilihat dari kondisi rumah, penghasilan, jumlah tanggungan dan pekerjaan. Data alternatif disajikan pada Tabel 1.

Tabel 1. Data Alternatif

\begin{tabular}{|c|c|c|c|c|c|}
\hline No. & Alternatif & $\begin{array}{l}\text { Kondisi } \\
\text { Rumah } \\
\end{array}$ & Penghasilan & $\begin{array}{c}\text { Jumlah } \\
\text { Tanggungan } \\
\end{array}$ & Pekerjaan \\
\hline 1 & Hani & 1 & 3 & 4 & 1 \\
\hline 2 & Japen & 2 & 5 & 5 & 5 \\
\hline 3 & $\begin{array}{c}\text { Noer } \\
\text { Azizah }\end{array}$ & 3 & 2 & 4 & 3 \\
\hline 4 & $\begin{array}{l}\text { Ahmad } \\
\text { Sodikin }\end{array}$ & 1 & 1 & 4 & 1 \\
\hline 5 & Suryani & 2 & 2 & 5 & 1 \\
\hline 6 & Rini & 2 & 4 & 4 & 3 \\
\hline 7 & $\begin{array}{l}\text { Ahmad } \\
\text { Khoirul }\end{array}$ & 2 & 3 & 5 & 4 \\
\hline 8 & Marup & 3 & 2 & 3 & 3 \\
\hline$\ldots$ & $\ldots$ & $\ldots$ & $\ldots$ & $\ldots$ & $\ldots$ \\
\hline 91 & Hasim & 2 & 2 & 3 & 3 \\
\hline
\end{tabular}


2. Menentukan Nilai Rating Setiap Alternatif pada Setiap Kriteria

Pada proses sistem pendukung keputusan penerima Bantuan Langsung Tunai diwilayah Desa Sukatenang. Dibutuhkan nilai rating pada setiap kriteria untuk membantu pihak Desa memilih alternatif yang terbaik sebagai penerima Bantuan Langsung Tunai. Adapun nilai rating setiap alternatif pada setiap kriteria disajikan pada Tabel 2.

Tabel 2. Nilai Rating Setiap Alternatif pada Setiap Kriteria

\begin{tabular}{|c|c|}
\hline Keterangan & Nilai \\
\hline Sangat Tinggi (ST) & 5 \\
\hline Tinggi $(\mathrm{T})$ & 4 \\
\hline Sedang (S) & 3 \\
\hline Rendah (R) & 2 \\
\hline Sangat Rendah (SR) & 1 \\
\hline
\end{tabular}

Kemudian memberikan nilai bobot pada setiap kriteria dengan skala 5 (Lima) ke dalam bilangan fuzzy, adapun pembobotan pada masing-masing kriteria disajikan pada Tabel 3, 4, 5, dan 6 sebagai berikut:

Tabel 3. Nilai Bobot Kriteria Kondisi Rumah

\begin{tabular}{cc}
\hline Keterangan & Nilai \\
\hline Bambu & 5 \\
Papan Biasa & 4 \\
Batu Bata & 3 \\
Merah & \\
Batako & 2 \\
Kaca & 1 \\
\hline Hasil Penelitian (2021)
\end{tabular}

Tabel 4. Nilai Bobot Kriteria Penghasilan

\begin{tabular}{cc}
\hline Keterangan & Nilai \\
\hline$<500$ & 5 \\
$500-1.000$ & 4 \\
$1.000-2000$ & 3 \\
$3.000-4.000$ & 2 \\
$4.000-5000$ & 1 \\
\hline Hasil Penelitian (2021)
\end{tabular}

Tabel 5. Nilai Bobot Kriteria Jumlah

\begin{tabular}{cc}
\multicolumn{2}{c}{ Tanggungan } \\
\hline Keterangan & Nilai \\
\hline Tidak Ada & 5 \\
1-2 Orang & 4 \\
3-4 Orang & 3 \\
5-6 Orang & 2 \\
7-8 Orang & 1 \\
\hline Hasil Penelitian (2021)
\end{tabular}

Tabel 6.Nilai Bobot Kriteria Pekerjaan

\begin{tabular}{cc}
\hline Keterangan & Nilai \\
\hline Tidak Bekerja & 5 \\
Petani & 4 \\
Pedagang & 3 \\
Buruh & 2 \\
Wiraswasta & 1 \\
\hline
\end{tabular}

Sumber: Hasil Penelitian (2021)

3. Memberikan nilai bobot preferensi atau tingkat kepentingan $(\mathrm{W})$.

$\mathrm{W}=[30 \%=0,30.20 \%=0.20 .30 \%=0,30$.

$20 \%=0.20]$

4. Membuat Matriks Keputusan

Matriks dibuat dari data alternatif serta kriteria yang didapat sebelumnya dari penyebaran kuesioner yang dilakukan. Matriks disajikan pada Tabel 7.

Tabel 7. Matriks Keputusan

\begin{tabular}{ccccc}
\hline Kode & $\begin{array}{c}\text { Kondisi } \\
\text { Rumah }\end{array}$ & Penghasilan & $\begin{array}{c}\text { Jumlah } \\
\text { Tanggungan }\end{array}$ & Pekerjaan \\
\hline A1 & 1 & 3 & 4 & 1 \\
A2 & 2 & 5 & 5 & 5 \\
A3 & 3 & 2 & 4 & 3 \\
A4 & 1 & 1 & 4 & 1 \\
A5 & 2 & 2 & 5 & 1 \\
A6 & 2 & 4 & 4 & 3 \\
A7 & 2 & 3 & 5 & 4 \\
A8 & 3 & 2 & 3 & 3 \\
$\ldots$ & $\ldots$ & $\ldots$ & $\ldots$ & $\ldots$ \\
A91 & 2 & 2 & 3 & 3 \\
\hline \multicolumn{5}{c}{ Sumber: Hasil Penelitian $(2021)$} \\
\end{tabular}

5. Membuat Perhitungan Proses Normalisasi Matriks Keputusan

Perhitungan selanjutnya adalah proses normalisasi. Normalisasi didapat dari perkalian setiap kriteria dengan max kriteria sesuai dengan persamaan (4). Hasil proses normalisasi disajikan pada Tabel 8.

Tabel 8. Proses Normalisasi Matriks Keputusan

\begin{tabular}{lllll}
\hline Kode & C1 & C2 & C3 & C4 \\
\hline A1 & 0.25 & 0.75 & 1 & 0.25 \\
A2 & 0.4 & 1 & 1 & 1 \\
A3 & 0.75 & 0.5 & 1 & 0.75 \\
A4 & 0.25 & 0.25 & 1 & 0.25 \\
A5 & 0.4 & 0.4 & 1 & 0.2 \\
A6 & 0.5 & 1 & 1 & 0.75 \\
A7 & 0.4 & 0.6 & 1 & 0.8 \\
A8 & 1 & 0.666667 & 1 & 1 \\
.. & $\ldots$ & & $\ldots$ & $\ldots$ \\
A91 & 0.66 & 0.66 & 1 & 1 \\
\hline Sumber: Hasil Penelitian $(2021)$ &
\end{tabular}

6. Melakukan Perkalian Matriks Ternormalisasi (R) dari Hasil Normalisasi Matriks (Rij) Hasil akhir dari perhitungan Simple Additive Weighting adalah perhtungan dari normalisasi setiap kriteria dikalikan dengan bobot vector (W) yang sudah ditentukan setelah itu 
dijumlahkan untuk hasil akhirnya. Hasil perhitungan disajikan pada Tabel 9.

Tabel 9. Hasil Perkalian Matriks Ternomalisasi

\begin{tabular}{cccccc}
\hline Kode & C1 & C2 & C3 & C4 & $\begin{array}{c}\text { Hasil } \\
\text { Akhir }\end{array}$ \\
\hline V1 & 0.05 & 0.225 & 0.2 & 0.075 & 0.55 \\
V2 & 0.08 & 0.3 & 0.2 & 0.3 & 0.88 \\
V3 & 0.15 & 0.15 & 0.2 & 0.225 & 0.725 \\
V4 & 0.05 & 0.075 & 0.2 & 0.075 & 0.4 \\
V5 & 0.08 & 0.12 & 0.2 & 0.06 & 0.46 \\
V6 & 0.1 & 0.3 & 0.2 & 0.225 & 0.825 \\
V7 & 0.08 & 0.18 & 0.2 & 0.24 & 0.7 \\
V8 & 0.2 & 0.2 & 0.2 & 0.3 & 0.9 \\
$\ldots$ & $\ldots$ & $\ldots$ & $\ldots$ & $\ldots$ & $\ldots$ \\
V91 & 0.1333 & 0.2 & 0.2 & 0.3 & 0.8333 \\
\hline
\end{tabular}

Sumber: Hasil Penelitian (2021)

Dari hasil pengujian yang dilakukan, maka terdapat nilai perangkingan dari yang paling tertinggi sampai terendah. Nilai tertinggi adalah V38=1.00 yang terpilih sebagai alternatif terbaik Penerima Bantuan Langsung Tunai.

Berdasarkan data perhitungan alternatif yang dilakukan, ada beberapa alternatif yang nilainya cukup untuk terpilih sebagai penerima Bantuan Langsung Tunai dengan kriteria yang sudah ditentukan. Alternatif terbaik disajikan pada Tabel 10.

Tabel 10. Altenatif Terbaik

\begin{tabular}{llll}
\hline ALTERNATIF & KODE & NILAI & RANK \\
\hline MAHMUDDIN & A38 & 1.00 & 1 \\
HAMID & A62 & 0.96 & 2 \\
SALIM & A86 & 0.93 & 3 \\
INTAN & A59 & 0.92 & 4 \\
JAJA & A57 & 0.9 & 5 \\
NURAKEM & A58 & 0.9 & 6 \\
UNAN & A66 & 0.9 & 7 \\
TUTI ALAWIYAH & A76 & 0.9 & 8 \\
NATA & A23 & 0.9 & 9 \\
MARUP & A86 & 0.9 & 10 \\
\hline
\end{tabular}

Sumber: Hasil Penelitian (2021)

\section{KESIMPULAN}

Bantuan Langsung Tunai sering dikenal dengan BLT yang merupakan salah satu program bantuan pemerintah dengan memberikan bantuan berupa uang tunai atau pun berbagai bantuan yang lain, yang bersyarat atau pun tidak bersyarat diberikan kepada masyarakat yang kurang mampu. Dari banyaknya jumlah penduduk yang mengusulkan BLT ini membuat pemerintah desa kesulitan untuk menyeleksi warga penerima BLT tersebut. Dengan demikian pemerintah Desa harus lebih teliti lagi dalam pemilihan warga yang akan diberi bantuan. Warga yang diberi benar-benar layak menerimanya dan dari golongan yang kurang mampu. Simple Additive Weighting dapat membantu untuk memecahkan masalah dengan menyeleksi di dalam perhitungan alternatif serta menentukan kriteria- kriteria yang sesuai dalam penerimaan program Bantuan Langsung Tunai tersebut secara tepat. Berdasarkan hasil perhitungan Simple Additive Weighting dalam menentukan penerima program Bantuan Langsung Tunai, alternatif dengan rank tertinggi adalah V38 $=1,00$ atau A38 dengan nama alternatif "Mahmuddin". Namun ada beberapa alternatif dengan nilai yang cukup dan tidak kurang dari 0,90 adalah A62, A86, A59, A57, A58, A66, A76, A23 dan A8 yang terpilih sebagai alternatif terbaik dalam penerima program Bantuan Lamgsung Tunai. Diharapkan dengan penelitian yang dilakukan ini dapat membantu pihak Desa untuk membuat keputusan yang lebih tepat dalam penentuan penerima program Bantuan Langsung Tunai sesuai dengan kriteria yang ditentukan

\section{REFERENSI}

Malik, A. Y., \& Haryanti, T. (2018). Penerapan Metode Analytical Hierarchy Process ( Ahp ) Untuk Sistem Pendukung Keputusan Pemilihan Program. Penerapan Metode Analitycal Hierarchy Process (AHP) Untuk Sistem Pendukung Keputusan Pemilihan Program, 14(1), 123-130.

Nandes, R. A., \& Yunus, Y. (2021). Sistem Pendukung Keputusan terhadap Jenis dan Penerima dalam Penentuan Bantuan Desa Menggunakan Metode Simple Additive Weighting. Jurnal Informatika Ekonomi Bisnis, 3 , 115-120. https://doi.org/10.37034/infeb.v3i3.85

Piasecki, K., \& Roszkowska, E. (2019). SS symmetry Simple Additive Weighting Method Equipped with.

Rahmawati, I. I., \& Apriyanto, R. (2021). Analisis Dan Perancangan Pemberian Bantuan Sosial Dampak COVID-19 Menggunakan Metode Simple Additive Weighting (SAW). POSITIF : Jurnal Sistem Dan Teknologi Informasi, 7(1), 31-43.

https://doi.org/10.31961/positif.v7i1.1075

Refiza. (2019). Penerapan Metode Simple Additive Weighting. Indonesian Journal on Computer and Information Technology, 4(2), 96-103. https://ejournal.bsi.ac.id/ejurnal/index.php/ijcit /article/viewFile/426/324\%0Ahttp://ejournal.b si.ac.id/ejurnal/index.php/ijcit/article/downloa $\mathrm{d} / 426 / 324$

Sahir, S. H., Rosmawati, R., \& Minan, K. (2017). Simple Additive Weighting Method to Determining Employee Salary Increase Rate. Ijsrst, 3(8), 42-48.

Santoso, S., \& Royal Kisaran, A. (2019). Sistem Pendukung Keputusan Seleksi Penerima Bantuan Sosial Untuk Keluarga Miskin Dengan Metoda Simple Additve Weighting (Saw). 
Journal of Science and Social Research, 4307(1), 21-28. http://jurnal.goretanpena.com/index.php/JSSR Sembiring, F., Fauzi, M. T., Khalifah, S., Khotimah, A. K., \& Rubiati, Y. (2020). Sistem Pendukung Keputusan Penerima Bantuan Covid 19 menggunakan Metode Simple Additive Weighting ( SAW ). Sistem Pendukung Keputusan Penerima Bantuan Covid 19 Menggunakan Metode Simple Additive Weighting (SAW), 11(2), 97-101.

Sobari, D., Sumanto, \& Indriani, K. (2017).
Pemilihan Santri Terbaik Menggunakan Metode Simple Additive Weighting. Konferensi Nasional Ilmu Sosial \& Teknologi (KNiST), 32-41.

Tan, S.-A., Sun, J., \& Ng, K. S. (2014). Full Scale Field Study of Jack-In Piles. 1(5), 532-545. https://doi.org/10.1061/9780784413265.043 